\title{
Examining Neolithic building and activity areas through historic cultural heritage in Jordan: a combined ethnographic, phytolith and geochemical investigation
}

\author{
Sarah Elliott, Carol Palmer, Samantha Lee Allcock and Emma Jenkins
}

\section{The INEA Project}

The INEA project (Identifying activity areas in Neolithic sites through Ethnographic Analysis of phytoliths and geochemical residues, https://research.bournemouth. ac.uk/2014/07/inea-project-2/) develops and applies a method that combines the analysis of plant remains (silica phytoliths) and geochemical residues to inform on construction methods and the use of space in recently abandoned historical villages and Neolithic settlements. It is a collaborative project based at Bournemouth University, in partnership with the Council for British Research in the Levant.

The historic village of Al Ma'tan in the At Tafila governorate was chosen for comparative analysis as a good example of a recently abandoned settlement providing a compelling analogy for earlier Neolithic sites (Fig. 1). For example, local clays, stone and plant materials were used in their construction; some of the structural elements were similar (such as the incorporation of raised sleeping platforms, moulded hearths, wall niches and clay food storage bins); the community was (and some still are) engaged in small-scale agriculture and animal husbandry. Furthermore, the former inhabitants of this village, who have re-located nearby, can inform on the history of the village, construction practices and specific activities that took place within the traditional houses in which they used to live. In this way, the project recorded the intangible as well as tangible heritage of Al Ma'tan.

\section{Traditional villages in Jordan}

Abandoned traditional villages dot Jordan's fertile highlands and are preserved to varying degrees, with some notably recorded and surveyed (see Biewers 1992; Khammash and Mhire 1986; Twaissi et al. 2016). Old villages and their vernacular architecture are an important part of Jordan's most recent phase of settlement and sedentarization that occurred in the late 19th and early 20th centuries. From the 1950s and 1960s onwards, as Jordan developed and introduced concrete building technology, the villages started to be abandoned or built over. For villages in difficult to access locations, people moved to new settlements beside major roads to take advantage of better access to services and employment. At the village of $\mathrm{Al} \mathrm{Ma'tan,} \mathrm{the} \mathrm{former} \mathrm{inhabitants} \mathrm{also} \mathrm{relate} \mathrm{that} \mathrm{they}$ moved to their new location in 'Ain al Bayda', some 2-3 $\mathrm{km}$ away, because the springs that once supplied them with abundant water resources dried up. A few families, however, continue to use some of the old village houses for keeping their sheep and goats, especially in winter.

In the At Tafila governorate (the study area of the INEA project) there are seven traditional villages: $\mathrm{Al} \mathrm{Ma'tan,} \mathrm{As}$ Sala, An Namta, Sinfiha, Busayra, Dana, and 'Ayma (Fig. 2). While many villages are falling into decay or being built over, some are finding new uses as part of tourism development. For example, a large number of houses in the village of Dana, at the heart of the RSCN's (Royal Society for the Conservation of Nature) Dana Biosphere Reserve, have been converted to
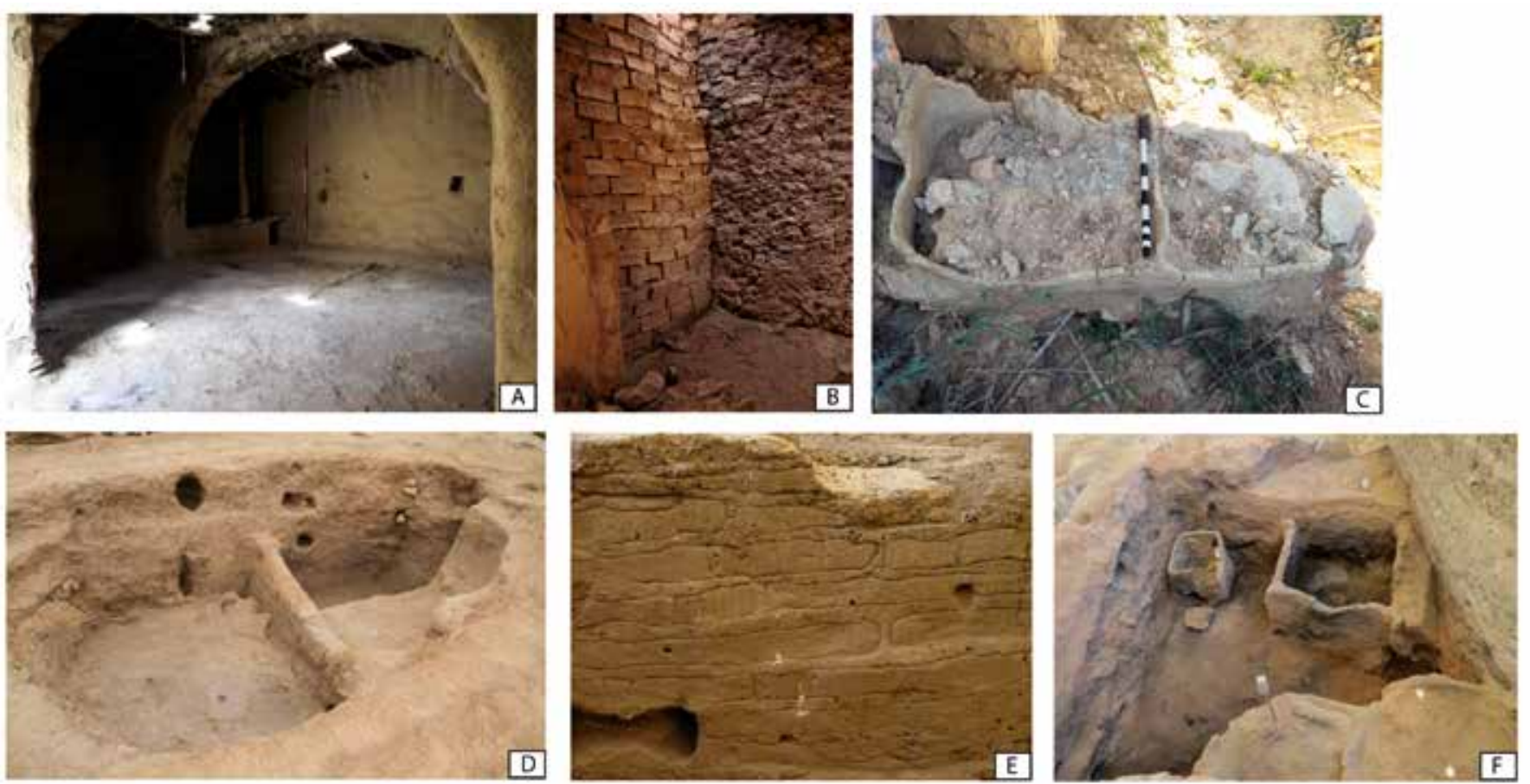

Fig. 1. A: Al Ma'tan building with niches and partitions; B: Al Ma'tan mudbrick wall; C: Al Ma'tan storage features; D: WF16, Jordan, Neolithic building with niches and partition; E: Çatalhöyük, Turkey Neolithic building with mudbricks; F: Çatalhöyük, Turkey, Neolithic building with storage features. Photographs by the INEA team and by kind permission of Steve Mithen and Bill Finlayson (WF16) and Eleni Asouti for Çatalhöyük. 

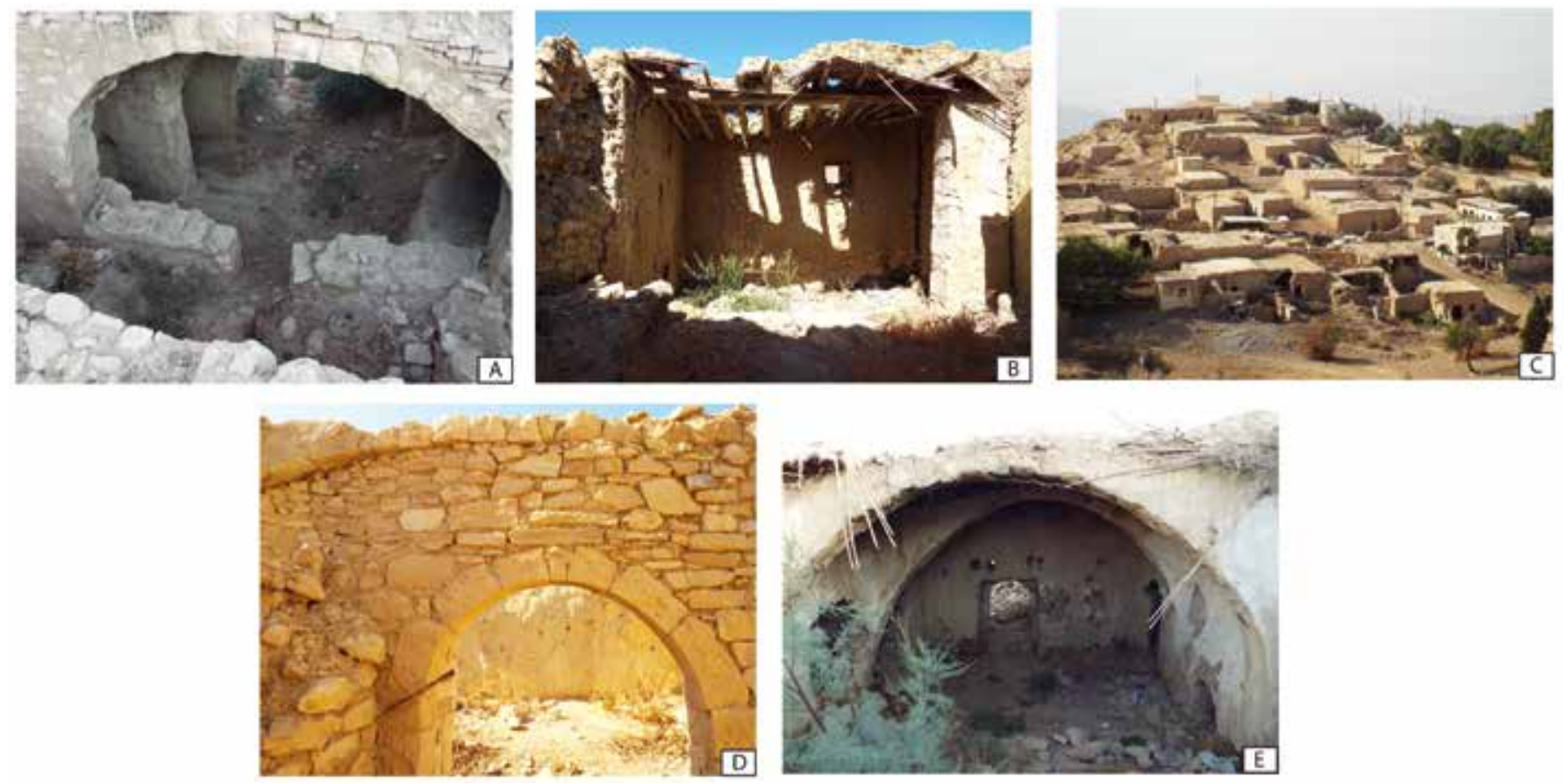

Fig. 2. A selection of images from old villages in the At Tafila governorate. A: Al Ma'tan; B: Dana; C: An Namta; D: As Sala; E: Sinfiha.

serve as hotel rooms for the Dana Hotel. Al Ma'tan and the nearby village of As Sala are currently the subject of on-going investment for visitor attractions as 'heritage' villages. Al Ma'tan has a visitor centre, eco-chalets under development and hosts a wide range of events, such as a folklore festival and yoga retreats, as well as being on the $650 \mathrm{~km}$ long Jordan Trail, a hiking route crossing the Kingdom from north to south. In As Sala some of the old houses have also been refurbished for use as visitor accommodation.

\section{Al Ma'tan}

The abandoned historic village of $\mathrm{Al} \mathrm{Ma'tan}$ near to At Tafila in southern Jordan (Fig. 3) was chosen for the INEA pilot study for two reasons: during the 2014 field season, a number of fairly intact, well-preserved houses with roofs and storage features were identified (Fig. 4) and, secondly, the Baquee'a Tourism Co-operative Society of Al Ma'tan is very engaged in promoting their village and its heritage as a local tourist attraction and welcomed our engagement.

The village Shabatat section of the Hamayda tribe own the village. The Head of the Co-operative is Mr Hussein Mohammad Shabatat (Abu Samr), who benefits from a wide network of contacts, which is how he came to the project members' attention. He was born in $\mathrm{Al} \mathrm{Ma'tan}$ (in one of the houses selected for study) and recollects how the village looked and what the people did there from his youth, some 50-60 years ago. He and members of the Co-operative were vital to the research project because they provided us with detailed information about individual houses, seasonal practices and the surrounding environment at the time of occupation.

The main building materials are stone, mud and plants. Concrete was used later, either as a wall plaster, for ironreinforced roofs, to make larger windows, or to reinforce and construct walls. The main architectural elements of the larger mud and stone old houses are arches (singular guntarah, plural ganater), walls and roofs. Foundations are minimal, with many buildings built directly into the hillside. The roofs, where they survive, are substantial, comprised of layers of juniper (Juniperus phoenicea), reed (Pharagmites australis), prickly shrubs (Sarcopoterium spinosum), known locally as 'Bilan', earth, and a mudstraw-water plaster mix on top called 'samaga' (Fig. 5). Additional rooms were added for storing agricultural equipment and tibn, chopped straw. Internal featuresstorage installations, sleeping platforms, fireplaces, niches, and shelves-were fashioned from mud, straw and water 'samaga' mix. The oldest houses do not have windows, but instead have openings above the doors and in the roof to provide ventilation and let out smoke. Other openings in the roof were used for pouring in stored products, mainly grain and tibn. Multiple related families shared these houses, living inside them chiefly in winter. Their primary function, year-round, was for storage.

The old village of $\mathrm{Al} \mathrm{Ma'tan} \mathrm{has,} \mathrm{in} \mathrm{part} \mathrm{or} \mathrm{in} \mathrm{whole,}$ over 100 structures as determined by INEA in 2014, which cover an area of approximately $150 \mathrm{~m} \times 100 \mathrm{~m}$ (Fig. 6). The structures range from large rectangular buildings with multiple arches and internal storage features to simple single-celled rooms. Many cluster around a central courtyard, likely representing a related, segmentary family unit. It is striking that the majority of walls are shared. Only four lanes run between the houses, though there are some separate homes away from the main housing units.

Three houses selected for analysis had partial or complete roofs and well preserved internal features (Fig. 4). They had internal partitions and storage areas as well as internal hearths still extant. In addition, external areas on the periphery of the village were selected for study including an area where there were once dung-fuelled ovens (sing. tabun; pl. tawabeen) used for cooking bread; another area which contained the ash dump, or 'midden', from these ovens was located just down the slope. The other external areas were sampled as control samples 


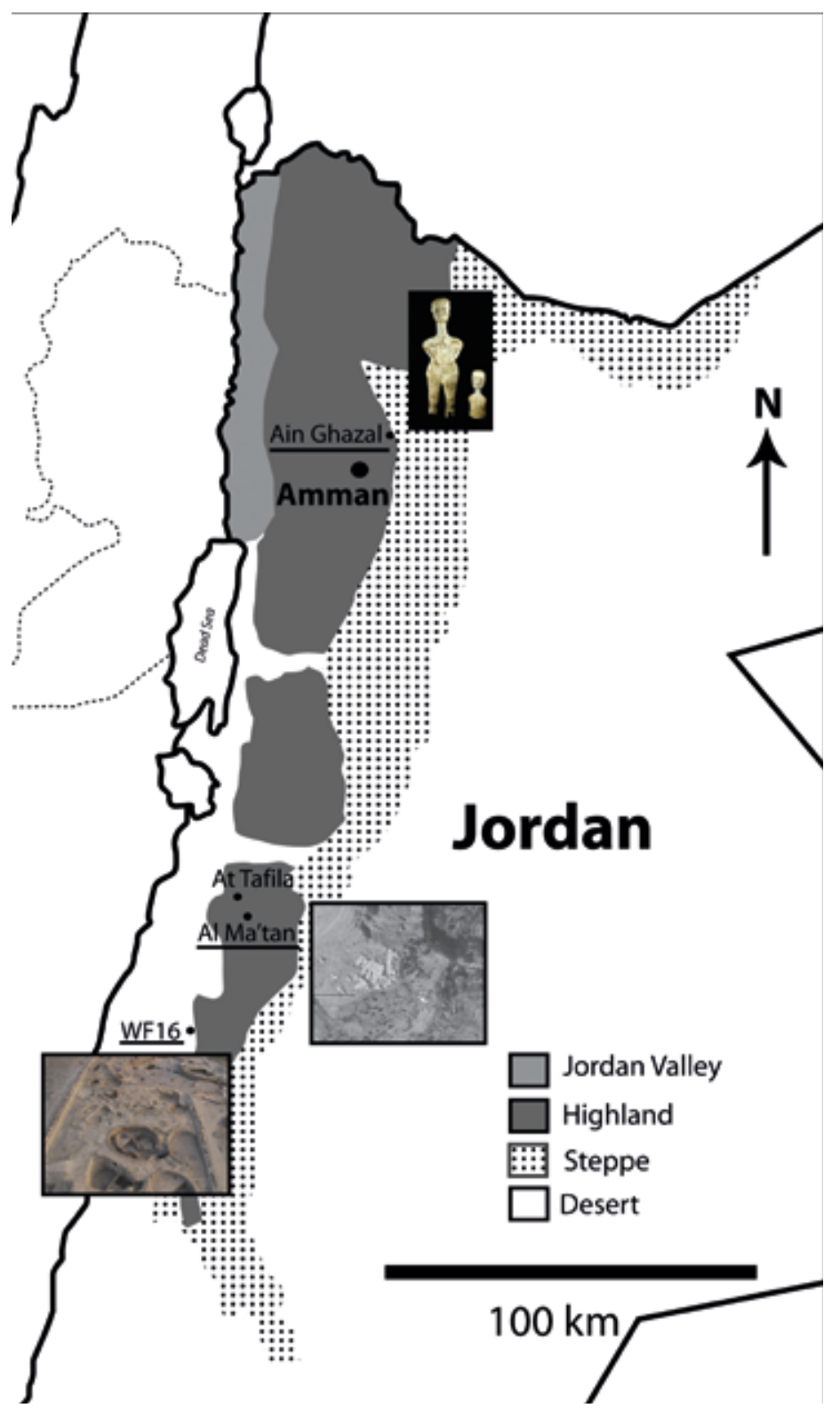

Fig. 3. Location of Al Ma'tan, WF16 and 'Ain Ghazal. Map by Sarah Elliott, images by kind permission of Gary Rollefson ('Ain Ghazal), Steve Mithen and Bill Finlayson (WF16). Al $M a^{\prime}$ tan is pictured from the Hunting Aerial Survey of Jordan (1953).
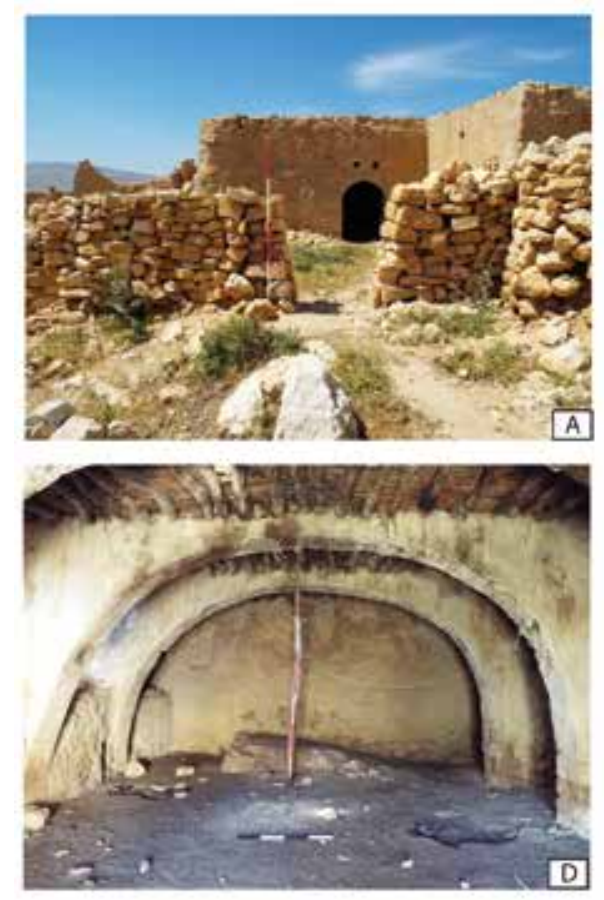
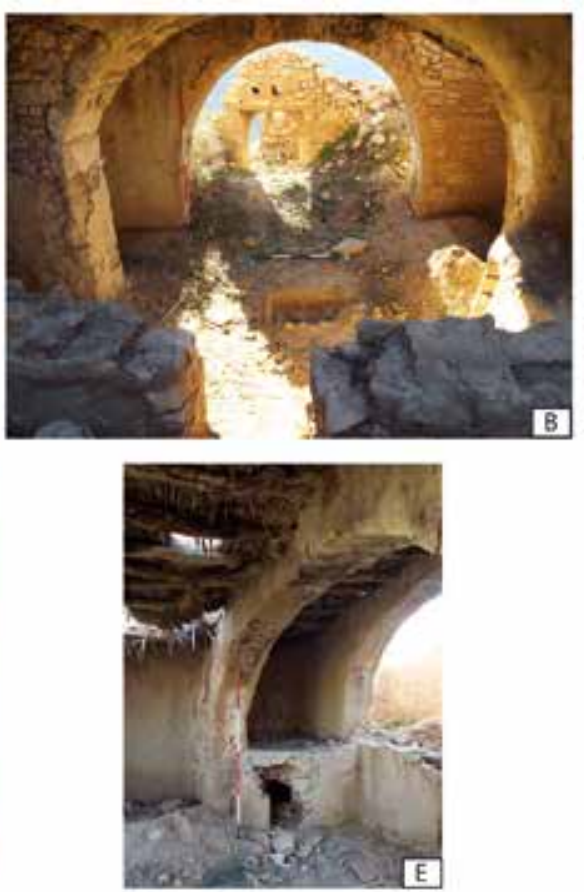
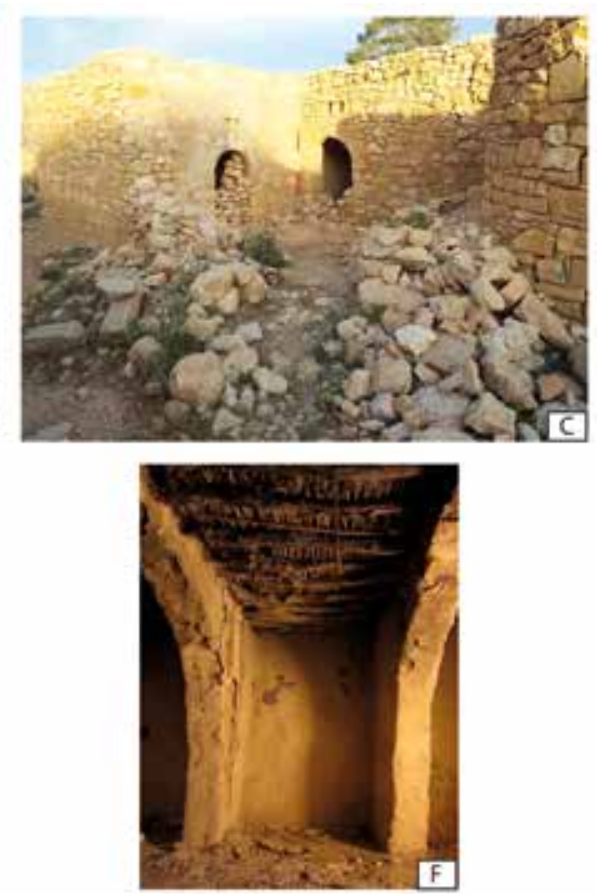

Fig. 4. Al Ma'tan-well-preserved houses. A and D: Building 1; B and E: Building 10; C and F: Building 65. 


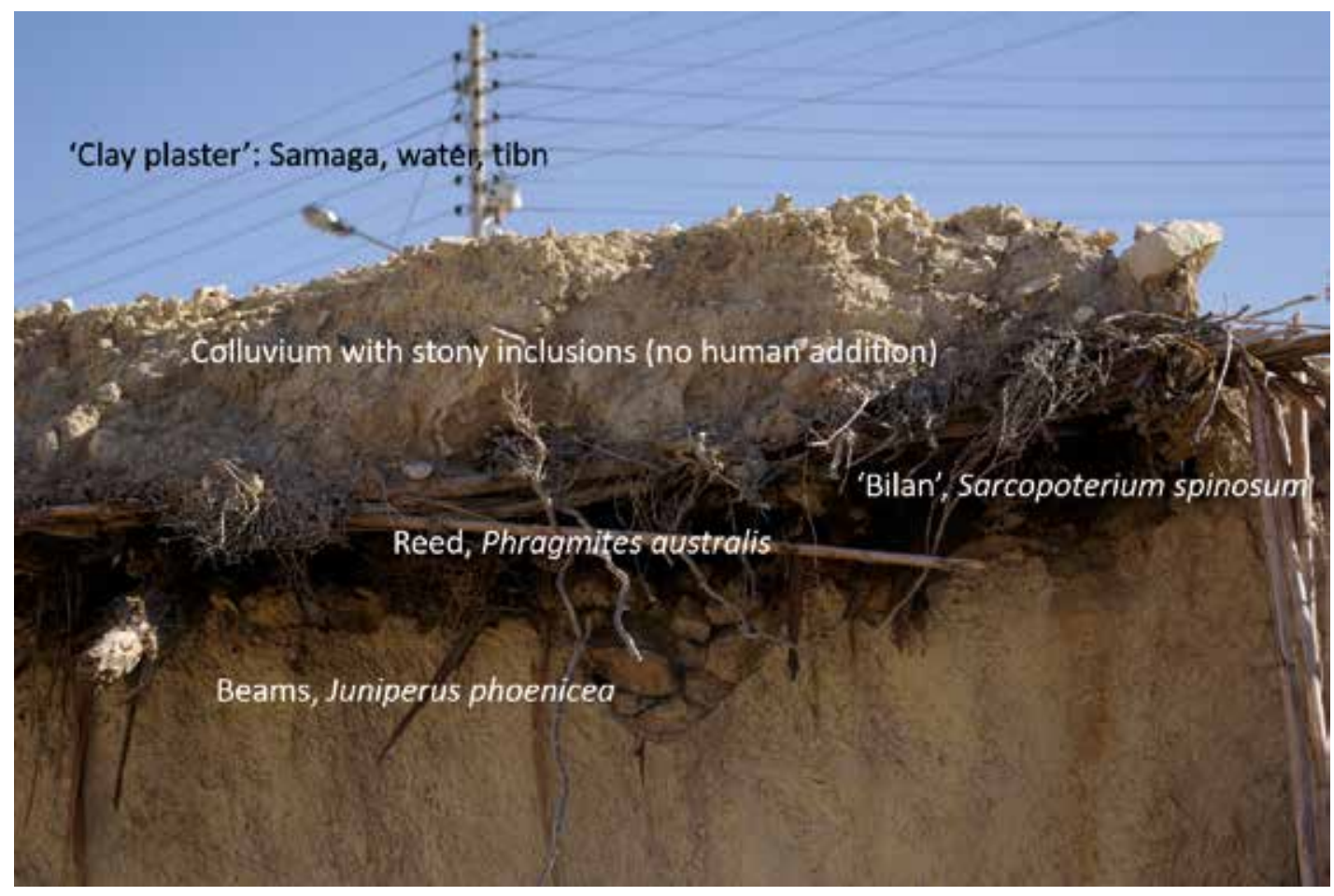

Fig. 5. Roofing materials from one of the houses at Al Ma'tan. Showing the different components used in roof construction: Juniperus phoenicea beams, Phragmites australis (reeds), 'Bilan' (Sarcopoterium spinosum), colluvium and clay plaster made from samaga (clay), tibn (temper) and water.

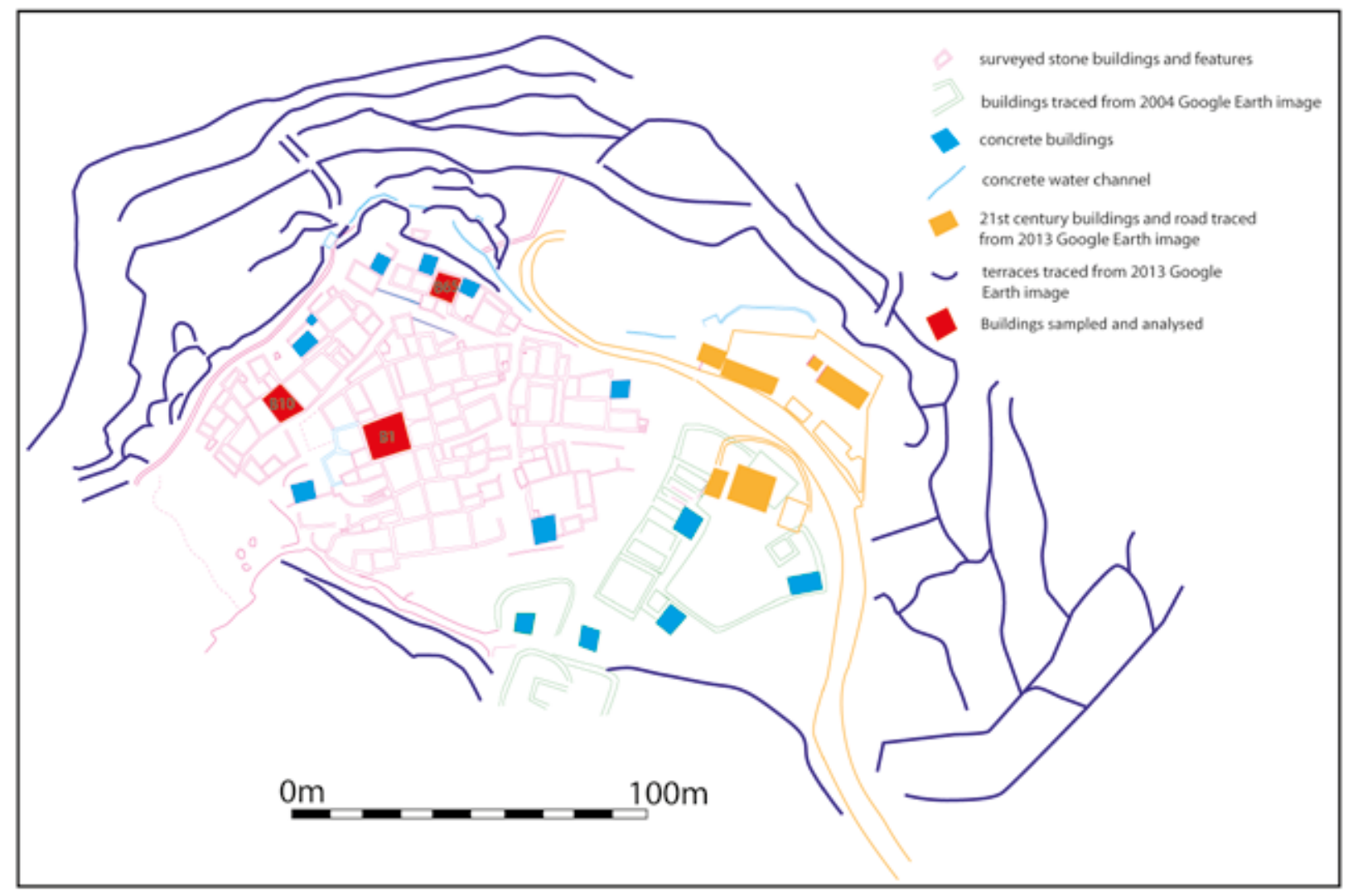

Fig. 6. Survey plan of Al Ma'tan village conducted in 2014. Mapping by Darko Maričević and Ben Ford.

including locations where clay was collected to make the 'samaga' mix and the agricultural terraces.

The former inhabitants of the three intensively studied houses provided information about the history of the house, for example, when it was constructed, who lived there, how the different internal features were used, where to find the 'samaga' clay to make plaster, and when the house was abandoned. The information gathered enabled targeting sampling and categorization for statistical analyses. 

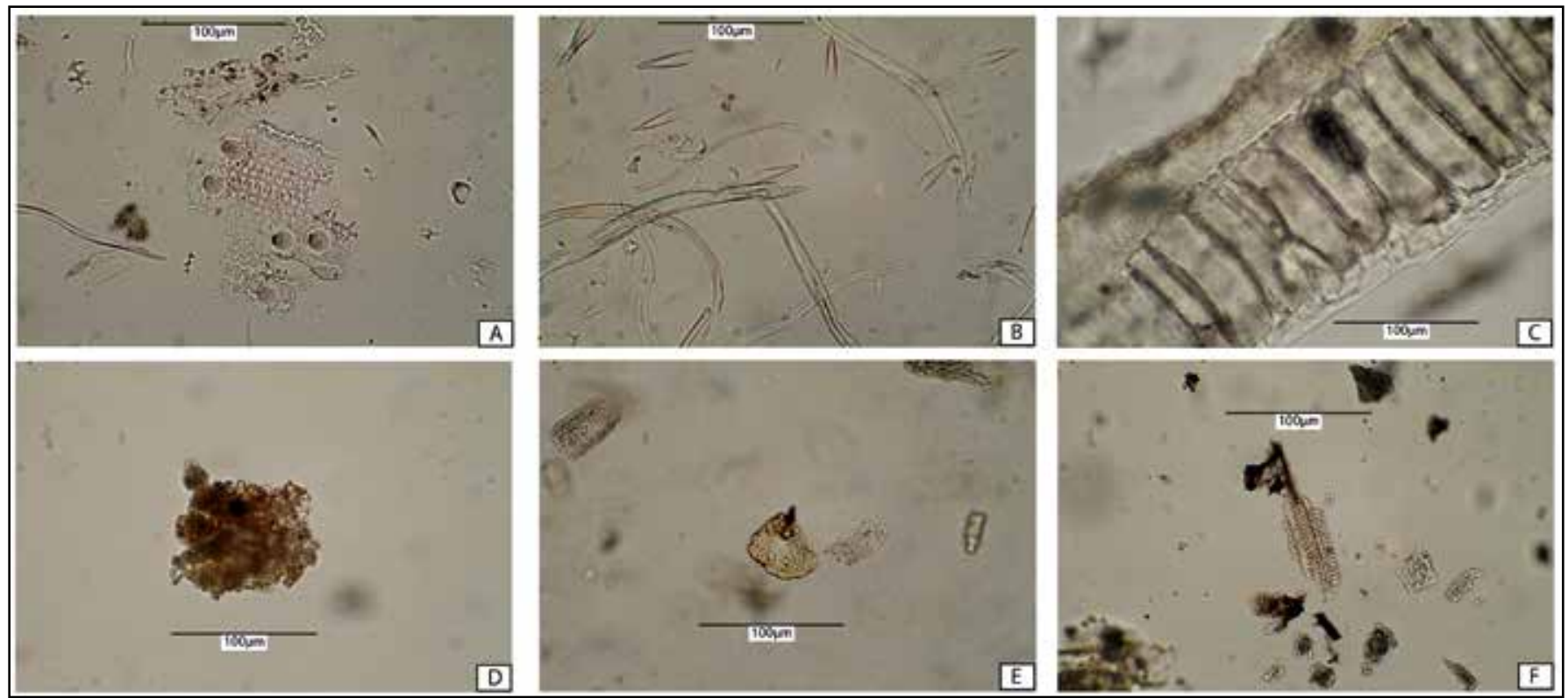

Fig. 7. Phytoliths identified in INEA phytolith reference collection. Monocots: A-Conjoined multicell from Avena barbata, showing elongate debritics and papillae; B-Hair phytoliths from awns of Hordeum spontaneum; C-Conjoined stacked bulliforms from Phragmites australis. Dicots: D-Silica Aggregate from Atriplex halimus; E-Platey from Eruca sativa; F-Tracheid from Hammada salicornia.
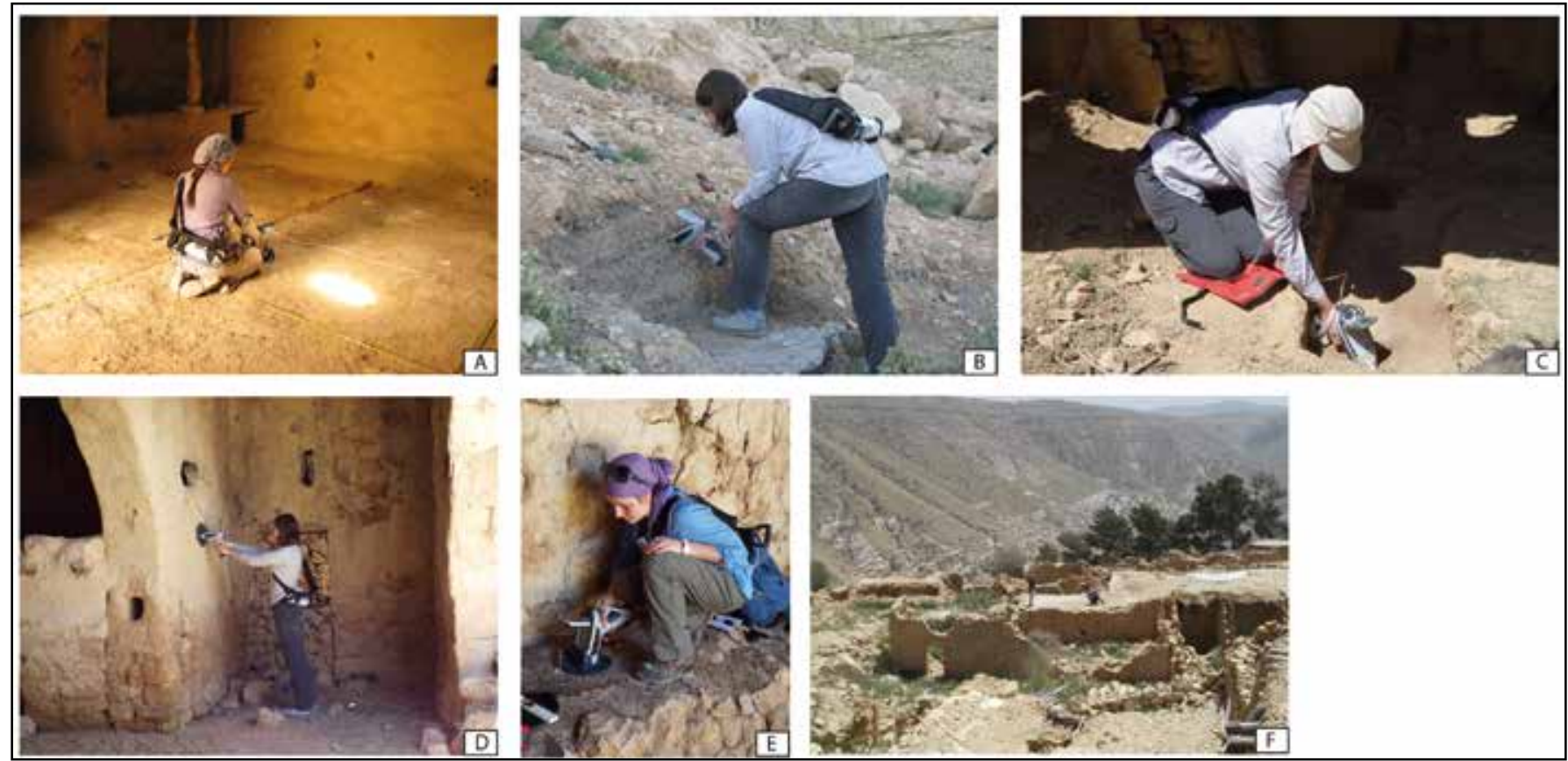

Fig. 8. Conducting in situ pXRF analysis at Al Ma'tan. A: floors in Building 65; B: midden material; C: hearth deposits in Building 10; D: walls in Building 93; E: platform in Building 93; F: roof of Building 1.

\section{Filming}

During fieldwork in 2014, the INEA project produced two short promotional films focussing on the cultural heritage of southern Jordan (beyond the classic Nabataean and Roman periods for which Jordan is so well known). The films were made under the direction of Vanessa Edwards (producer) and Andy Marsh (filming). Over two weeks, the film crew recorded a range of archaeological sites and landscapes and conducted interviews of local inhabitants and archaeologists working in the region. The first film aimed to raise awareness of Jordan's diverse heritage to tourists. The second promoted archaeology as a subject to aspiring students. These films highlight the stunning local landscape, vernacular architecture and village forms that extend back 12000 years into the Neolithic. They can be found by following the links below, and can be shared:

- Jordan: Looking Forward to the Past: https: / / www. youtube.com/watch?v=lgBorKvoDLo

- Undertaking Archaeology as a Subject: https: / / www. youtube.com/ watch? v=ao4vVcfvyuE

The tourist film was premiered in Jordan at the visitor centre in Al Ma'tan in June 2015 to coincide with the opening of the new eco-chalets that were under construction at the time of fieldwork in 2014. 


\section{Scientific analyses}

A range of structural components were targeted and sampled for scientific analyses including: plasters, roofs, floors, middens, hearths, platforms and external spaces. These samples were analysed for phytoliths, silica bodies that form in and around plant cells (Fig. 7) and geochemistry. Different geochemical elements may indicate the deposition of specific components such as ash or shell, e.g. calcium (Ca) (Sullivan and Kealhofer 2004: 1669), or may represent defined activities such as burning e.g. Potassium (K) (Middleton and Price 1996).

The geochemical and phytolith results from Al Ma'tan have been compared with samples from similar contexts at the Neolithic sites of Wadi Faynan 16 (WF16) and 'Ain Ghazal (Fig. 3). WF16 is a Pre-Pottery Neolithic A (PPNA) site in southern Jordan (Fig. 13) with the excavated deposits dating to $c .11840 \mathrm{cal} \mathrm{BP}$ to $c .10240 \mathrm{cal}$ BP (Wicks et al. 2016). The architectural remains from WF16 are predominantly circular semi-subterranean structures with pisé walls. 'Ain Ghazal dates from the later Pre-Pottery Neolithic B (PPNB) period (c. 9200 BP) into the Yarmukian period (c. $7000 \mathrm{BP}$ ) and is situated within the Greater Amman Municipality (Fig. 3) (Rollefson and Kafafi 2013). Most of the architecture at 'Ain Ghazal consists of rectangular stone-walled buildings with mud mortar. The construction materials at both archaeological sites are comparative to the materials used at of the modern case study Al Ma'tan.

A portable $x$-ray fluorescence ( $\mathrm{pXRF}$ ) instrument was used to distinguish the presence of 36 geochemical elements from in situ sediments at $\mathrm{Al} \mathrm{Ma'tan} \mathrm{(Fig.} \mathrm{8).} \mathrm{The}$ samples taken from WF16 and 'Ain Ghazal were analysed using the same equipment and parameters; however, some samples were analysed ex situ. Elements below the limit of detection $(<\mathrm{LOD})$, or with high error readings (typically $>10 \%$ ), were removed before statistical analysis. The retained elements were subjected to statistical investigation using Principle Components Analysis (PCA) (see Jenkins et al. 2017: for full results).

Small samples (2-5 g) were taken from the in situ sediments analysed with the pXRF on site at Al Ma'tan and sent to Bournemouth University for phytolith extraction and microscopic investigation. Phytoliths were identified and categorized into monocotyledonous (typically from grasses) and dicotyledonous types (typically from shrubs and trees) with the aid of a modern reference collection produced by the project. Single-celled phytoliths were counted and quantified to a minimum of 250 . Multicelled, or conjoined, phytoliths were counted to a minimum of 50 multicells, where feasible. The results of the phytolith analysis were also analysed using PCA statistical analysis. The results from these two datasets, geochemical and phytolith, were considered first separately and then together to establish whether samples within specific categories exhibited patterning according to context.

\section{Results}

At Al Ma'tan the PCAs show that certain contexts have distinctive signatures, especially for the geochemical data (Jenkins et al. 2017). The phytolith data reveals useful patterning but is less easy to interpret due to the high number of variables within the dataset. The combined results of the geochemical and phytolith analyses reveal three key signature clusters in the PCA (Table 1) (Jenkins et al. 2017). The first cluster (C1) includes controls, mortars, and hearth make-up (hearth construction materials and debris from use) categories that are distinct because of higher levels of titanium (Ti), calcium (Ca) and magnesium $(\mathrm{Mg})$, and phytoliths favourably comparable with woody plant and reed species. The second distinct group (C2) includes storage features, plasters and clay features, platforms and benches, and floor and surfaces categories which group together because of elevated levels of, primarily, calcium (Ca) and chlorine $(\mathrm{Cl})$, as well as phytoliths from the leaf and stem portions of plants, mainly grasses. The third group (C3) includes animal occupation, external fire installations and ashy deposits, and midden categories, and variables such as potassium (P), sulphur (S), and dendritic phytoliths that are used in archaeology to trace the presence of cereals. So, individual categories did not produce a standalone activity signature but categories of similar origin or similar construction material did. For

\begin{tabular}{|c|c|c|c|}
\hline & Categories & $\begin{array}{l}\text { Cluster influenced by } \\
\text { geochemical elements: }\end{array}$ & $\begin{array}{l}\text { Cluster influenced by } \\
\text { phytoliths from: }\end{array}$ \\
\hline \multirow{3}{*}{ Cluster 1} & control/background & \multirow{3}{*}{$\mathrm{Ti}, \mathrm{Ca}, \mathrm{Mg}$} & \multirow{3}{*}{ Trees/shrubs, reeds } \\
\hline & mortar & & \\
\hline & hearth make-up & & \\
\hline \multirow{4}{*}{ Cluster 2} & storage feature & \multirow{4}{*}{$\mathrm{Ca}, \mathrm{Cl}$} & \multirow{4}{*}{ Grass leaf/stems } \\
\hline & plasters and clay features & & \\
\hline & platforms and benches & & \\
\hline & floor and surfaces & & \\
\hline \multirow{3}{*}{ Cluster 3} & animal occupation & \multirow{3}{*}{$P, S$} & \multirow{3}{*}{ Grass husks } \\
\hline & external fire installations and ashy deposits & & \\
\hline & midden & & \\
\hline
\end{tabular}

Table 1. Clustering of categories based on $p X R F$ geochemistry results and phytolith results for Al Ma'tan, Wadi Faynan 16 and 'Ain Ghazal. These categories and clusters are influenced by certain phytoliths and geochemical elements; however, they are not solely defined by the influenced elements/phytoliths. These elements and phytoliths also occur across categories. 
instance, categories made from the same source material of clay and straw mix plot together in cluster 2 (C2). There was some evitable blurring of category groups, but on the whole, phytolith and geochemical analysis assisted in differentiating between broader contexts and tallied with the information provided by the former inhabitants.

Our analyses show that some of the ethnographic samples from Al Ma'tan have comparable signatures to those from the Neolithic study sites, but there also interesting differences (Table 2). Unfortunately, samples for some categories were not available at the archaeological sites, limiting comparisons.

Where contexts could be compared across two or three sites, the differences in activity signatures could be pinpointed to three main reasons. Firstly, that samples from similar contexts stem from different geological areas and vegetation zones, making the base background material and therefore the phytolith and geochemical component of samples slightly different between the sites. Secondly, the age of each site is too important, especially considering the phytolith remains. The phytolith results at the early Neolithic site of WF16 reveal low numbers of phytoliths and the dominance of tree and shrub plants. Whereas at 'Ain Ghazal and Al Ma'tan, phytolith numbers are elevated and grass phytolith types are more important, including cereals (with extremely high proportions of grass and cereal phytolith remains present at $\mathrm{Al}$ Ma'tan). This likely reflects the adoption and increasing use of grasses and domesticated cereals over time. Thirdly, the life history of the context was also significant in driving the phytolith and geochemical differences. Variation was greatest for samples that originated from 'multipurpose' contexts (such as middens or floors) that would have been used by different people, for different reasons and for different lengths of time.

For these reasons, building and construction materials are very influential in creating distinctions between categories. At all three sites, there are clear differences between floors and surfaces, and between plasters and clay features (Table 2) because these contexts were formed from materials extracted from different local geologies and are based on different technological developments. For example, the lime plaster floors with red ochre surfaces at
'Ain Ghazal and the choice of temper material (if any) in the mud plasters at WF16 and Al Ma'tan. Greater signature similarities therefore exist for contexts that are more akin to an activity than a construction such as fire contextsactivities that are alike no matter the geology and age of site. Internal fire installations and ashy deposits and external fire installations and ashy deposits are comparably high in sulphur (S), potassium $(\mathrm{K})$ and phosphorus $(\mathrm{P})$, and to some extent calcium (Ca) (Table 2). Choice, however, still plays a major role even for comparable activities because the choice of fuel use strongly influences how similar the fire contexts are. Dung appears as a fuel choice at Al $\mathrm{Ma}^{\prime} \tan$ for external fires, but it is not clear whether it was used either at WF16 or 'Ain Ghazal.

Generally, the use of phytolith remains on their own make defining signatures hard, but the presence of certain phytolith types or dissimilarities in phytolith counts improve the interpretation of certain contexts. Here we have presented only a summary of the main similarities and differences between samples in all categories sampled at each site (see Table 2). The publication of the full scientific results of the ethnographic and archaeological case studies are due to be published soon and a full comparison and interpretation can therefore be seen in the forthcoming publication (Allcock et al. in prep).

\section{Conclusions and future work}

This most recent Jordanian heritage provides important information for use in archaeological studies, and there are potential analogies beyond the Neolithic period in the later prehistoric and historic past. In the future, the INEA project aims to record more modern villages to establish whether or not the patterns from $\mathrm{Al} \mathrm{Ma'tan}$ are replicated at other similar recently abandoned, traditionally-built villages. Originally, the team had intended to study the neighbouring village of As Sala as well as Al Ma'tan, but the size of the village and richness of the deposits meant we limited our initial study to Al Ma'tan. With further studies, a more extensive ethnoarchaeological database can be established, and the methods piloted here can be implemented as standard for archaeological

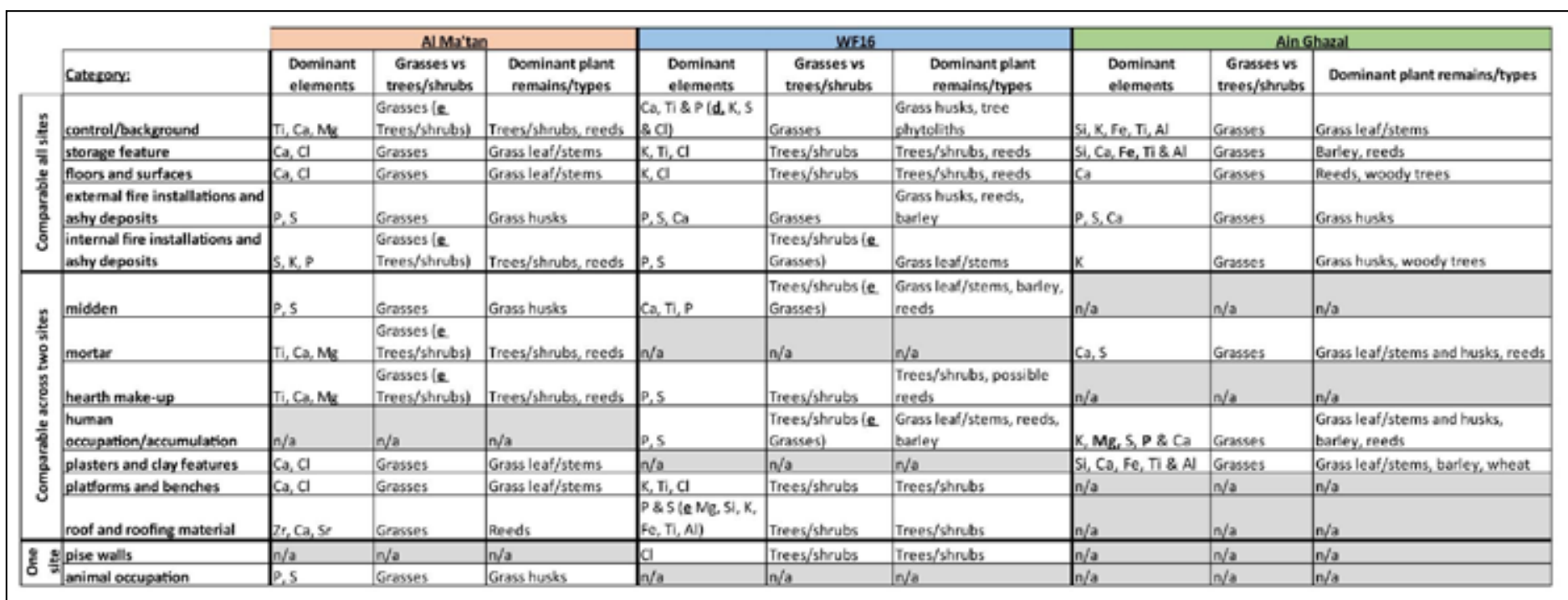

Table 2. Table comparing all categories across all sites. Similarities and differences highlighted between main geochemical elements and plant remains. Grey $(n / a)$-samples not analysed from this category at this site, $\underline{\boldsymbol{e}}$-elevated but not dominant, $\underline{\boldsymbol{d}}$-depleted. 